\title{
Al-Ṭahțāwī in Paris: Western Influence on Format and Style in Early Modern Arabic Travel Literature
}

Ibrahem Almarhaby*

College of Liberal Arts \& Science, Department of Classical and Modern Languages, Literatures and Cultures, Detroit, Michigan, USA, Department of Arabic language and literature, Jouf University, Saudi Arabia

Corresponding Author: Ibrahem Almarhaby, E-mail: khloofh@hotmail.com

\section{ARTICLE INFO}

Article history

Received: December 11, 2017

Accepted: January 26, 2018

Published: January 26, 2018

Volume: 9 Issue: 1

Advance access: January 2018

Conflicts of interest: None

Funding: None

\begin{abstract}
This study investigates format and style in the first modern Arab travel source, Takhlis al-Ibriz fi Talkhiṣ Paris, written by Sheikh al-Ṭahtāwī in the $19^{\text {th }}$ century. During this century, the connection between the Eastern Self and the Western Other became closer and more immediate culturally and politically, which undeniably impacted literature on both thematic and artistic levels. This paper addresses the extent to which the format and style of al-Ṭahțāwī was influenced by the Other and to determine how these artistic aspects had changed and were distinct from those aspects in medieval travel literature.
\end{abstract}

Key words:

Travel Literature,

Arabic Literature,

The Self,

The Other,

Modern Arabic Travel Literature,

Literature

\section{INTRODUCTION}

The nineteenth century is a significant era in which modern travelogue literature developed from the medieval model on both thematic and artistic levels due to changes in colonial conditions and closer and stronger connections with the West. Accordingly, the prose area of the travelogue text of Takhlis al-Ibriz fi Talkhis Paris [The extraction of pure gold in the abridgement of Paris] will be the primary source for exploration of this Western influence.

Takhlis includes an introduction which contains four parts, and six essays, each of which includes various sections. The third essay, which contains thirteen sections and is titled "In the Description of Paris and Its Civilization", is the core of the book; indeed al-Ṭahțāwī (18011873) mentions in the introduction that this essay is the major purpose of his writing. Therefore, this essay contains voluminous and considerably detailed information, despite which, as he acknowledges, he cannot do justice to the whole scope and variety of this great city (Newman, 130). For this reason, this paper concentrates mainly on the thirteen sections of this third essay and partly on the fourth, fifth, and sixth essays in all their sections for ana- lytical and critical investigation of the Western influence on format and style.

Before al-Ṭahțāwī traveled to the West, he was educated by many of the prestigious scholars of al-Azhar al-Sharif, a traditional school in Egypt which concentrates solely on Islamic and Arabic language studies. The educational system in such a school usually required a classical Arabic writing style because the educational system utilized rote memorization, in which all students follow their 'A $\lim$ Imam in learning. This method of learning is reflected in almost all sources published in Arabic or Islamic domains before and during his lifetime. Sheikh Hassan al-'Attar (1766-1835), was one of the most significant scholars who taught al-Ṭahțāwī the traditional forms of knowledge and whatever other kinds of knowledge may not have been taught in al-Azhar at that particular time for religious reasons, such as history, geography, literature, etc. (Hasan, 22, 26). After traveling in the West, al-Ṭahtāīī was greatly influenced by Western scientific and cultural ideas, which was reflected in his travelogue text. Such Western influence along with his cultural background produced an overlap in his writing style, language and content which is where we can grasp his fascination with and 
influence by the Other. The writing style and format is in fact closer to modern standard Arabic language than to classical Arabic.

\section{METHODOLOGY}

The methodology that this study is based on is simultaneously analytical and descriptive. These approaches are useful to the critical reading of this voluminous source in deducing the Western impacts on style and format. As the source has already been translated by Newman D. in 2004, we can therefore base the discussion on this translation.

\section{STYLE AND FORMAT}

The first Eastern-Western friction for al-Ṭahțāwī was with the French language, which he started learning by rote. In his introduction, al-Ṭahțāwi acknowledges that educational attainment in French is quite easy compared to Arabic because French unlike Arabic does not use homographs, synonyms, and complicated grammar. This explicit acknowledgement indicates the Western impact on his literary style as he completely avoids the adoption of superfluous rhyme and homographs and utilizes facilitative language as he mentions in his introduction (Newman, 100 \& Lūqā, 158). Al-Ṭahțāwī's tendency to use a classical Arabic writing style for the beginning of the Takhlis and modern standard Arabic during the middle and end characterizes his travelogue and distinguishes it from the previous travelogues available in the $19^{\text {th }}$ century. At the beginning of the Takhliș, we can observe that al-Ṭahțāwi utilizes the writing style of classical Arabic sources where he starts with the traditional introduction that includes the statement of purpose of his travel, the mention of fellow travelers, and the narrative of reasons for his travels. The Takhlis, as other sources had before and during his time, starts with classical rhymed prose, religious textual quotations and poems. His utilization of the Basmala [An Arabic phrase meaning "in the name of God"], the phrase I'lam [know that], and the long titles at the beginning of the prefatory and introductory sections along with the aforementioned notes are all indicative of the traditional and cultural influences that were prevalent at this time (Lūqā, 90, 151). Furthermore, al-Ṭahțāwī adopted rhyme in some contexts only in order to make them interesting to the implied reader, as he strictly avoided it in the context of discussing scientific themes and issues and in comparisons between the Self and the Other. In this way he dramatically navigated his writing style in the Takhlis from the weak Arabic literary writing style of previous years, which involved much embellishment with unfruitful purpose, into a more highly evolved stage, which represents the return of artistic merit in Arabic writing style ('Amārah, 119).

However, despite these signs of evolution in writing style, four different markers indicate that some of the classical Arabic writing style features remain present in the Takhliș's writing style. First, the Takhlis in its initial draft contained a great many linguistic and syntactic errors, and a number of colloquial terms and expressions that were poorly worded. Al-Ṭahțāwī also included many derogatory words and terms for Islamic customs as well as others for Western people, like the term "disbelievers" instead of Christians, etc. Such observations were highlighted by his mentor Jomard who advised al-Ṭahțāwi to make changes, which he did after he returned to his native land (Newman, 90, Lūqā, 141). The fair criticism for these mistakes can be established by two justifications. The first is that the primary reason for al-Ṭahțāwi to be with the Egyptian scientific mission to France was to be a Muslim religious leader (Imam) for the students (Newman, 38). Thus, he was a student and a religious leader; hence, he had two primary positions on the mission, and a secondary one which was to record his observations on his travels in the West. Therefore, due to his lack of time with the two primary positions, he was rapidly noting every new observation and comment in the secondary one; hence, it was natural for such issues to arise in his writing. The other justification is that alTahțāwi aimed to follow a path of simplicity in the usage of language in the Takhlis, as he mentioned in the introduction, in order to enable people with varying levels of education to read his travelogue. However, his extreme attention to this led him to engage in vernacular and modern standard Arabic (Lūqā, 141, Newman, 100).

The second marker is that Takhlis includes voluminous detail about the Other which is absolutely natural due to the traveler's desire to be as comprehensive as he claimed to be in his introduction. However, several areas of the book contain a great deal of unhelpful digressions and circumlocutions. His excessive linguistic explanation and analysis of several French terms, for instance, is disruptive of the flow of the text. The reason behind that probably returns to the Arabic culture that he was taught in writing style, where Arabs in Arabic and Islamic studies often utilize a great deal of linguistic interpretation and analysis of new terms.

The third marker can be observed in al-Ṭahtāwî̀'s massive number of Arabic poem citations, for example, that indicate his firmly held relationship with his culture and ancient heritage; however, these citations become redundant and tedious because no section nor even a page in the Takhliṣ could exist without some cited poems. Some justifications have been presented by Arab researchers such as 'Amārah, in Rifā'ah Al-Ṭahțāwì $R$ ā'd al-tanwīr F̄̄ al-'așr al-Hadìth [Rifă'ah Al-Ṭahțāwī: The Pioneer of the Enlightenment in the Modern Era], which addressed al-Ṭahțāwī’s repeated usage of cited poems. As 'Amārah reminds us, one of al-Tahțāwī's goals during his time in France was to be a religious leader; therefore, he felt he had to mention these citations in his travelogue with his future students in mind. Although it is true that al-Ṭahtāiwi was a religious leader for Egyptian students, a number of these citations were added by al-Ṭahtāwī when he returned to Egypt. Moreover, any connection between the cited poems and the context in which they were used is tenuous (Newman, 91 \& Lūqā, 143-44); hence, reconsideration of such previous views is extremely significant. The last marker is seen in the sheer volume of repetition in the Takhliṣ. Al-Ṭahțāwī aimed to describe the West with Eastern audiences in mind, so he demarcated his description of the Other in the Takhlis into several domains, as seen in the third essay of the source. However, due to his 
overambitious explanations in some areas, he fell into the trap of redundant repetition. In the description of the Other's scientific and cultural knowledge, for instance, which should be, according to his organization, fully described in the specified section which is number thirteen of the third essay, he also indicates them in the second section of the introduction, the second and the thirteenth sections of the third essay, the fifth section of the fourth essay, and the whole of the sixth essay. Al-Tahtāiñ was conscious of the issue of repetition as he mentioned at the beginning of the fifth section of the fourth essay. However, instead of editing the mentioned data in the specified place, section thirteen, and adding the new information to it, he listed the new information in addition (Hijāzī, 292, 332).

\section{CONCLUSION}

Al-Ṭahtāwī's cultural background, along with the adoption of a Western literary writing style, generated a fusion of Arab and French literary styles in the Takhlis, which sets apart his writing style from others before and during his time. Despite the similarity of the format at the beginning of the Takhlis to those of the medieval Arabic era, as he progressed, alṬahțāwī remarkably substituted his traditional literary writing style for a new Western literary one. He disposed of the full usage of classical Arabic language, exaggerated rhyme that seems apparent in the title of the Takhlis and in a few places in its opening sections, and departed from using long titles at the beginning of each section to bring us gradually to a more facilitative language, explanation, and description in a new framework. This, in itself, in terms of writing style, is a significant development that distinguishes it from previous travelogues available during his time.

\section{REFERENCES}

Al-Ṭahțāwī, R. (1988). Takhliṣ al-Ibriz fì Talkhiṣ Paris. [Translated from Arabic by]: Newman, Daniel, (2004). An Imam In Paris: Account of a Stay in France by an Egyptian Cleric (1826-1831). (1 ${ }^{\text {st }}$ Ed.). London: SAQI.

Amarah, M. (2007). Rifā'ah Al-Ṭahțāwì $R$ à'd al-tanwīr $F \bar{\imath}$ al-'așr al-Hadīth. Cairo: Dār al-Shurūk.

Hasan, M. (1993). Silsilat Nawābigh al-Fikr al-'Arabī: Hasan al-'Attar. (2 ${ }^{\text {nd }}$ Ed.). Cairo: Dār al-Ma〉 ārif.

Hijāzī, M. (1974). Ușūl Al-Fikr al-'Arabī al-Ḥad̄̄th 'Inda al-Tahțāwī, Ma 'aa al-Nașṣ al-Kāmil Likitābihī “Takht̄̄s al-ibrīz. Cairo: Alhai'ah al-Mașriyyah al- ‘āmah llkitāb.

Lūqā, A. (1997). 'Awdat Rifā'ah al-Ṭahțāwī; Marāhil Istifāqat al-Fikr F̄̄ Daw' Al-Adab Al-Muqāran.Tunisia: Dār al-Ma'ārif. 